\title{
Editorial
}

\section{Welcome to Seminars in Thrombosis \& Hemostasis 2014}

\author{
Emmanuel J. Favaloro, PhD, FFSc (RCPA) ${ }^{1}$ \\ ${ }^{1}$ Department of Haematology, Institute of Clinical Pathology and \\ Medical Research (ICPMR), Westmead Hospital, Westmead, \\ New South Wales, Australia
}

Semin Thromb Hemost 2014;40:11-16.

Welcome to the beginning of another year with Seminars in Thrombosis \& Hemostasis (STH). This is my 6th year as Editor in Chief, and my 9th year of editorial association with this journal, having previously served as a Regional Editor. First, I sincerely wish to thank all the contributors to STH over past years, as well as the Guest Editors for these issues, and of course, the Senior and Associate Editors of the journal. There are no planned changes to the editorial team for 2014. This is also a fitting time to announce that this year represents the 40th year of publication for this journal, a milestone that we will celebrate with a special 40th Anniversary Celebratory issue. This issue will be scheduled as either the last issue of 2014 , or the first of 2015 , depending on progress.

I will also take this opportunity to thank the journal production team at Thieme Medical Publishers for their high production standards and for facilitating both the print and online issues of the journal. In particular, I would like to thank Sangeeta PC who leads the production team and who until recently was the Production Editor for STH. Sangeeta has had to recently give up this particular role due to increasing other commitments, and so Subhankar De will now undertake this role. As Subhankar has essentially acted (and performed admirably) in this role for the past 6 months, I am sure that he will continue to do so. Finally, I wish to thank Kelly Coffey, a Journals Coordinator for Thieme Medical Publishers, as well as other key people at Thieme, some of who prefer to remain unnamed, for additional support provided over the past year.

I think this is also a fitting time to once again reflect on our journal's Impact Factor, which for 2012 was 4.216, which represents a small drop from our 2011 Impact Factor of 4.524 (-Fig. 1). I do not want to make too much of this change, except to say that this may mean we will see some stabilization of the STH Impact Factor at around 4 over coming years. I have previously highlighted, ${ }^{1,2}$ and would continue to assert, that the Impact Factor is not the only marker of journal "quality" that we should consider, given

Address for correspondence Emmanuel J. Favaloro, PhD, FFSc (RCPA), Department of Haematology, Institute of Clinical Pathology and Medical Research (ICPMR), Westmead Hospital, Westmead, NSW 2145, Australia (e-mail: emmanuel.

favaloro@health.nsw.gov.au).

the existence of other biometric markers and the limitations of any individual marker (including the Impact Factor) as a "quality" indicator.

While on such discussion, I would also like to draw the readership's attention to DORA, a document otherwise known as The San Francisco Declaration of Research Assessment, which has been sponsored/signed by more than 150 scientists and 75 scientific organizations (www.ascb.org/SFdeclaration.html). This declaration derived from deliberations held during the 2012 American Society for Cell Biology meeting and stipulates that the Journal Impact Factor must not be used as a surrogate measure of the quality of individual research articles, to assess an individual scientist's contributions, or used in hiring, promotion, and funding decisions. The declaration further recommends alternative metrics for evaluating researchers, including citation counts of individual articles. Further discussion around these recommendations and DORA are available online (www.ascb. org/SFdeclaration.html), including a response from the suppliers of the Impact Factor Thomson Reuters (http://researchanalytics.

\section{Seminars in Thrombosis \& Hemostasis}

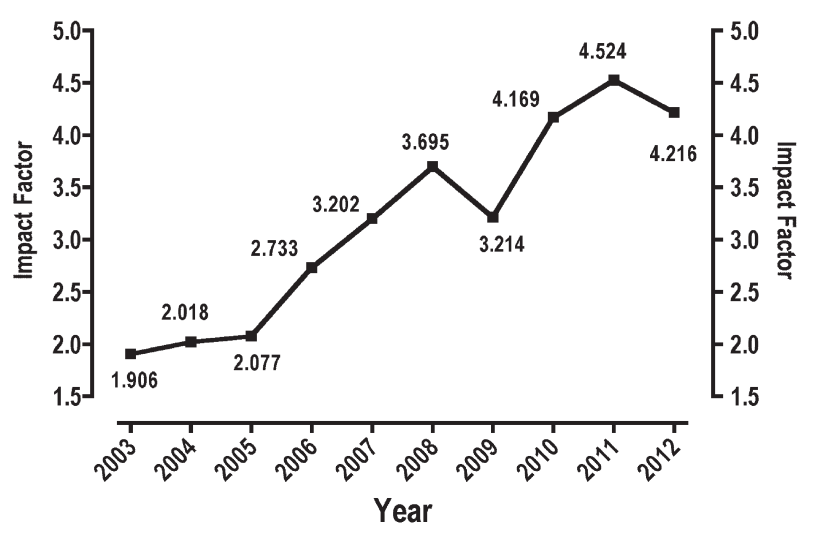

Fig. 1 Seminars in Thrombosis \& Hemostasis: Impact factor by year.

Copyright $\odot 2014$ by Thieme Medical Publishers, Inc., 333 Seventh Avenue, New York, NY 10001, USA. Tel: +1(212) 584-4662.
DOI http://dx.doi.org/ $10.1055 / \mathrm{s}-0033-1364202$. ISSN 0094-6176.
Issue Theme Hot Topics V; Guest FFSC (RCPA). 
Seminars in Thrombosis \& Hemostasis

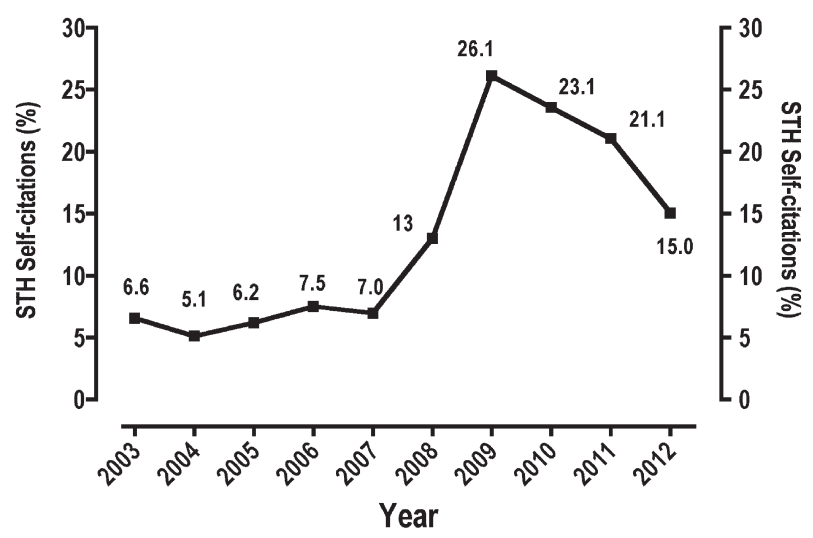

Fig. 2 Seminars in Thrombosis \& Hemostasis: Recent self-citations by year.

thomsonreuters.com/statement_re_sfdra/). The publisher of $\mathrm{STH}$, Thieme Medical Publishers, is in support of the declaration, and I will also herein provide my own personal in principle endorsement of this declaration. Several members of the STH editorial board have also endorsed the sentiments of DORA.

Perhaps this is then also a fitting time to reconsider the role of self-citations in the impact factor, which I have also mentioned in previous years. ${ }^{1,2}$ The self-citation rate for STH over recent years is shown in -Fig. 2. There are several aspects that I would like to point out. Over the past decade, the self-citation rate had initially increased from a low of $6 \%$ in 2003 to a peak of $\sim 26 \%$ in 2009 and has more recently fallen steadily to $\sim 15 \%$ in 2012 . Let me assert here that STH does not have any official policy that aims to promote unnecessary self-citations. However, STH does strive to be an integrated journal, meaning that we will on occasion refer to previous publications if these are relevant to the topic at hand. In essence, most of the STH self-citations from recent years as noted in - Fig. 2 appear in either (i) my annual celebratory editorials (such as this one) which highlight our past successes-either those STH papers most popular among our readership $^{3-7}$ or those most highly cited,,$^{8-11}$-or (ii) the Prefaces for each issue, which essentially identify the contributions within that issue as well as summarizing their content and significance. It does seem true that STH did have a relatively high self-citation rate among peer journals a few years ago, but this was certainly not due to solicited selfreferencing, as perhaps recently inferred. ${ }^{12}$ Indeed, I will make no apologies for the above noted self-citations, which I see as valid within the context of usage over these years. The years from 2008 to 2010, in particular, represented a period of significant change for STH, with protracted illness and eventual passing of the Founding Editor, Eberhard F. Mammen, in 2008, and with editorial changes that saw my taking over the role of Editor in Chief. ${ }^{13-15}$ Those years also saw several celebratory editorials and an entire celebratory issue dedicated to Eberhard F. Mammen and highlighting his contribution to STH and to the field of thrombosis and hemostasis in general. ${ }^{16,17}$ This time period also represented the initiation
Table 1 Recent self-citation rates of some journals publishing in the field of thrombosis and hemostasis

\begin{tabular}{|l|l|l|}
\hline \multirow{2}{*}{ Journal } & \multicolumn{2}{|c|}{ Year } \\
\cline { 2 - 3 } & 2011 & 2012 \\
\hline Seminars in Thrombosis \& Hemostasis & 21.1 & 15.0 \\
\hline Journal of Thrombosis and Haemostasis & 11.5 & 8.5 \\
\hline Thrombosis and Haemostasis & 20.9 & 16.2 \\
\hline Blood Coagulation and Fibrinolysis & 16.4 & 11.6 \\
\hline Thrombosis Research & 8.0 & 14.4 \\
\hline Blood & 11.5 & 10.8 \\
\hline
\end{tabular}

Note: Journal self-citation rates are given for Impact Factor years 2011 and 2012 and represent the percentage of self-citations that are used for calculating the Journal Impact Factor for that year. Data from Thomson Reuters ISI Web of Science.

of our issue-integrated prefaces. It is expected that the STH self-citation rate will now stabilize around the value of 15$20 \%$, a rate that is similar to those of other journals in the field of Thrombosis and Hemostasis (-Table 1). For those of you interested, I have also plotted the "self-citation adjusted" impact factor trend for STH (i.e., impact factor excluding the self-citations) in - Fig. 3. I have also previously suggested that journal self-citations could be handled by Thomson Reuters by provision of two-paired "impact factor" values, one with self-citations included and the other without. ${ }^{2}$

Given the mention of DORA above, and its recommendation to continue to promote alternative metrics to the Journal Impact Factor, I have also provided a plot of the STH 2-year citation rates from SCImago (http://www.scimagojr.com/) (-Fig. 4). Although this measure provides a similar metric to that of the Journal Impact Factor, the data derives from the use of an alternative publication database, and so provides an independent data set, which (importantly) is also currently freely available.

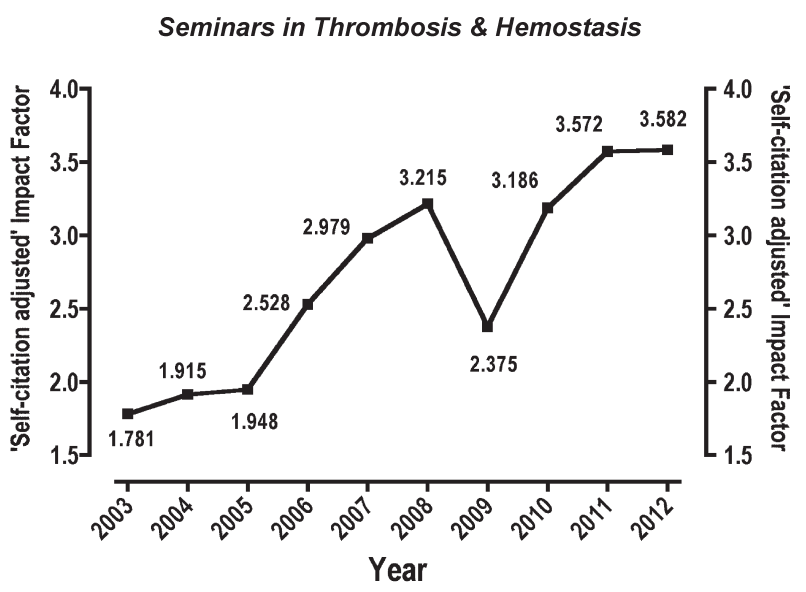

Fig. 3 Seminars in Thrombosis \& Hemostasis: "Self-citations-adjusted" impact factors by year. 


\section{Seminars in Thrombosis \& Hemostasis}

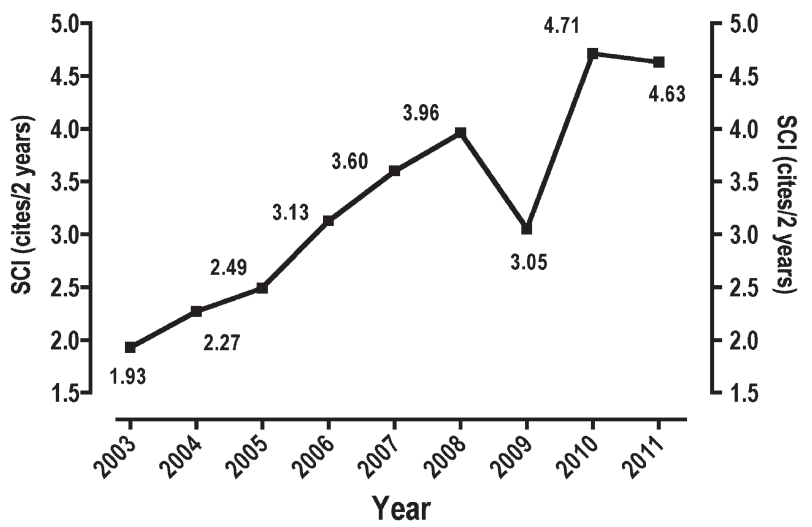

Fig. 4 Seminars in Thrombosis \& Hemostasis: $\mathrm{SCl}$ citations per 2 years.
Nevertheless, the Journal Impact Factor currently remains the best-recognized metric of article "popularity." Accordingly, I have listed the top 46 (2012-cited; 2010/ 2011-published) contributions from this journal in - Table 2. ${ }^{18-63}$ These contributions identify those most contributing to the 2012 Impact Factor, and each was cited 6 or more times in 2012. The top 15-listed articles ${ }^{18-32}$ were each cited 10 or more times in 2012, and the first four contributions $^{18-21}$ were each cited an impressive 20 or more times. A review of this list also highlights that the two issues most contributing to this achievement were "Microparticles in thrombosis and hemostasis," 64 guest edited by Nigel S. Key and Hau C. Kwaan in 2010, and "Coagulopathies and thrombosis: usual and unusual causes and associations, part III," ${ }^{65}$ guest edited by Emmanuel J. Favaloro, Giuseppe Lippi, and Massimo Franchini. For those interested, the current listing (-Table 2) can be compared

Table 2 Top 46 most highly cited articles in Seminars in Thrombosis \& Hemostasis ${ }^{\mathrm{a}}$

1. Rak J. Microparticles in cancer. Semin Thromb Hemost 2010;36(8):888-906

2. Nagy JA, Chang SH, Shih SC, Dvorak AM, Dvorak HF. Heterogeneity of the tumor vasculature. Semin Thromb Hemost 2010;36 (3):321-331

3. Lippi G, Franchini M, Favaloro EJ, Targher G. Moderate red wine consumption and cardiovascular disease risk: beyond the "French paradox". Semin Thromb Hemost 2010;36(1):59-70

4. Amabile N, Rautou PE, Tedgui A, Boulanger CM. Microparticles: key protagonists in cardiovascular disorders. Semin Thromb Hemost 2010;36(8):907-916

5. Lacroix R, Robert S, Poncelet P, Dignat-George F. Overcoming limitations of microparticle measurement by flow cytometry. Semin Thromb Hemost 2010;36(8):807-818

6. Köse O, Zimmerhackl LB, Jungraithmayr T, Mache C, Nürnberger J. New treatment options for atypical hemolytic uremic syndrome with the complement inhibitor eculizumab. Semin Thromb Hemost 2010;36(6):669-672

7. Fava C, Montagnana M, Favaloro EJ, Guidi GC, Lippi G. Obstructive sleep apnea syndrome and cardiovascular diseases. Semin Thromb Hemost 2011;37(3):280-297

8. Favaloro EJ. Von Willebrand disease: local diagnosis and management of a globally distributed bleeding disorder. Semin Thromb Hemost 2011;37(5):440-455

9. de Moerloose P, Boehlen F, Neerman-Arbez M. Fibrinogen and the risk of thrombosis. Semin Thromb Hemost 2010;36(1):7-17

10. Tse D, Stan RV. Morphological heterogeneity of endothelium. Semin Thromb Hemost 2010;36(3):236-245

11. Volz HC, Kaya Z, Katus HA, Andrassy M. The role of HMGB1/RAGE in inflammatory cardiomyopathy. Semin Thromb Hemost 2010;36(2):185-194

12. Levi M, Schultz M, van der Poll T. Disseminated intravascular coagulation in infectious disease. Semin Thromb Hemost 2010;36 (4):367-377

13. Zhou Z, Nguyen TC, Guchhait P, Dong JF. Von Willebrand factor, ADAMTS-13, and thrombotic thrombocytopenic purpura. Semin Thromb Hemost 2010;36(1):71-81

14. Wiinberg B, Kristensen AT. Thromboelastography in veterinary medicine. Semin Thromb Hemost 2010;36(7):747-756

15. Tufano A, Coppola A, Cerbone AM, Ruosi C, Franchini M. Preventing postsurgical venous thromboembolism: pharmacological approaches. Semin Thromb Hemost 2011;37(3):252-266

16. Gonzalez E, Pieracci FM, Moore EE, Kashuk JL. Coagulation abnormalities in the trauma patient: the role of point-of-care thromboelastography. Semin Thromb Hemost 2010;36(7):723-737

17. Favaloro EJ. Laboratory testing in disseminated intravascular coagulation. Semin Thromb Hemost 2010;36(4):458-467

18. Key NS, Mackman N. Tissue factor and its measurement in whole blood, plasma, and microparticles. Semin Thromb Hemost 2010;36(8):865-875

19. Linkins LA, Warkentin TE. Heparin-induced thrombocytopenia: real-world issues. Semin Thromb Hemost 2011;37(6):653-663

20. Lippi G, Franchini M, Favaloro EJ. Thrombotic complications of erythropoiesis-stimulating agents. Semin Thromb Hemost 2010;36(5):537-549

21. Franchini M, Di Minno MN, Coppola A. Disseminated intravascular coagulation in hematologic malignancies. Semin Thromb Hemost 2010;36(4):388-403

22. Daub K, Seizer P, Stellos K, et al. Oxidized LDL-activated platelets induce vascular inflammation. Semin Thromb Hemost 2010;36(2):146-156

23. Phang M, Lazarus S, Wood LG, Garg M. Diet and thrombosis risk: nutrients for prevention of thrombotic disease. Semin Thromb Hemost 2011;37(3):199-208

24. Lassila R, Antovic JP, Armstrong E, et al. Practical viewpoints on the diagnosis and management of heparin-induced thrombocytopenia. Semin Thromb Hemost 2011;37(3):328-336 
25. Franchini M, Lippi G. Recombinant activated factor VII: mechanisms of action and current indications. Semin Thromb Hemost 2010;36(5):485-492

26. Koenen RR, Weber C. Platelet-derived chemokines in vascular remodeling and atherosclerosis. Semin Thromb Hemost 2010;36(2):163-169

27. Flaumenhaft R, Mairuhu AT, Italiano JE. Platelet- and megakaryocyte-derived microparticles. Semin Thromb Hemost $2010 ; 36$ (8):881-887

28. Karpman D, Sartz L, Johnson S. Pathophysiology of typical hemolytic uremic syndrome. Semin Thromb Hemost 2010;36 (6):575-585

29. Targher G, Zoppini G, Moghetti P, Day CP. Disorders of coagulation and hemostasis in abdominal obesity: emerging role of fatty liver. Semin Thromb Hemost 2010;36(1):41-48

30. Ochoa CD, Wu S, Stevens T. New developments in lung endothelial heterogeneity: Von Willebrand factor, P-selectin, and the Weibel-Palade body. Semin Thromb Hemost 2010;36(3):301-308

31. Khankin EV, Royle C, Karumanchi SA. Placental vasculature in health and disease. Semin Thromb Hemost 2010;36(3):309-320

32. Orth D, Würzner R. Complement in typical hemolytic uremic syndrome. Semin Thromb Hemost 2010;36(6):620-624

33. Turecek PL, Schrenk G, Rottensteiner H, et al. Structure and function of a recombinant von Willebrand factor drug candidate. Semin Thromb Hemost 2010;36(5):510-521

34. Stellos K, Seizer P, Bigalke B, Daub K, Geisler T, Gawaz M. Platelet aggregates-induced human CD34+ progenitor cell proliferation and differentiation to macrophages and foam cells is mediated by stromal cell derived factor 1 in vitro. Semin Thromb Hemost 2010;36(2):139-145

35. De Franceschi L, Cappellini MD, Olivieri O. Thrombosis and sickle cell disease. Semin Thromb Hemost 2011;37(3):226-236

36. Allman-Farinelli MA. Obesity and venous thrombosis: a review. Semin Thromb Hemost 2011;37(8):903-907

37. Maas C, Oschatz C, Renné T. The plasma contact system 2.0. Semin Thromb Hemost 2011;37(4):375-381

38. Trigg DE, Wood MG, Kouides PA, Kadir RA. Hormonal influences on hemostasis in women. Semin Thromb Hemost 2011;37 (1):77-86

39. Muszbek L, Bereczky Z, Bagoly Z, Shemirani AH, Katona E. Factor XIII and atherothrombotic diseases. Semin Thromb Hemost 2010;36(1):18-33

40. Little KM, Smalley DM, Harthun NL, Ley K. The plasma microparticle proteome. Semin Thromb Hemost 2010;36(8):845-856

41. Molema G. Heterogeneity in endothelial responsiveness to cytokines, molecular causes, and pharmacological consequences. Semin Thromb Hemost 2010;36(3):246-264

42. Lisman T, Porte RJ. The role of platelets in liver inflammation and regeneration. Semin Thromb Hemost 2010;36(2):170-174

43. Dragon-Durey MA, Blanc C, Garnier A, Hofer J, Sethi SK, Zimmerhackl LB. Anti-factor H autoantibody-associated hemolytic uremic syndrome: review of literature of the autoimmune form of HUS. Semin Thromb Hemost 2010;36(6):633-640

44. Coppola A, Tagliaferri A, Franchini M. The management of cardiovascular diseases in patients with hemophilia. Semin Thromb Hemost 2010;36(1):91-102

45. Bigalke B, Krämer BF, Seizer P, Fateh-Moghadam S, Gawaz M, Lindemann S. Diagnostic and therapeutic potentials of platelet glycoprotein VI. Semin Thromb Hemost 2010;36(2):203-211

46. van der Post JA, Lok CA, Boer K, Sturk A, Sargent IL, Nieuwland R. The functions of microparticles in pre-eclampsia. Semin Thromb Hemost 2011;37(2):146-152

aPublished in 2010 or 2011 and cited 6 or more times in 2012.

Table 3 Current planned topics for future issues of Seminars in Thrombosis \& Hemostasis include

- Hot topics: A short history of thrombosis and hemostasis (40th anniversary issue)

- Quality in thrombosis and hemostasis (continued)

- Thrombotic complications in cancer patients

- Clinical management of hemophilia

- Platelet function testing/disorders

- Hemolytic uremic syndrome/thrombotic thrombocytopenic purpura

- Inflammation, endothelial dysfunction and thromboembolism

- Hemostasis in the elderly with those of the most recently published top-50 downloaded article listings from Seminars in Thrombosis $\mathcal{E}$ Hemostasis, the basis of the Eberhard F. Mammen "Most Popular" awards. ${ }^{5-7}$ Accordingly, I would like to thank all the contributors, guest editors, and the editorial team for bringing us the content that makes Seminars in Thrombosis E Hemostasis.

Finally, a short note to confirm that the editorial team will continue to develop plans for the future content of this journal, and we are confident that we will be able to continue to bring you, the readers, the high quality content that you have come to expect from this journal. Currently confirmed topics for issues that we plan to publish over the next 12 or so months are listed in - Table $\mathbf{3}$. At the same time, we recognize the need to retain some flexibility in our plans and to potentially add additional material of current interest and controversy as the need arises.

We look forward to another interesting year of reading in 2014! Happy birthday STH. 


\section{References}

1 Favaloro EJ. The Journal Impact Factor: don't expect its demise any time soon. Clin Chem Lab Med 2009;47(11):1319-1324

2 Favaloro EJ. Measuring the quality of journals and journal articles: the impact factor tells but a portion of the story. Semin Thromb Hemost 2008;34(1):7-25

3 Favaloro EJ. Editorial: Winners of the inaugural Eberhard F Mammen award for most popular article. Semin Thromb Hemost 2009; 35:587-590

4 Favaloro EJ. Winners of the 2010 Eberhard F. Mammen award for most popular article during 2008-2009. Semin Thromb Hemost 2010;36(7):685-692

5 Favaloro EJ. 2011 Eberhard F. Mammen award announcements. Semin Thromb Hemost 2011;37(5):431-439

6 Favaloro EJ. 2012 Eberhard F. Mammen award announcements. Semin Thromb Hemost 2012;38(5):425-432

7 Favaloro EJ. 2013 Eberhard F. Mammen award announcements. Semin Thromb Hemost 2013;39(6):567-574

8 Favaloro EJ. Farewell to 2009!. Semin Thromb Hemost 2009;35(8): 715-718

9 Favaloro EJ. Editorial. Farewell to 2010!. Semin Thromb Hemost 2010;36(8):797-802

10 Favaloro EJ. Editorial-Farewell 2011. Seminars in Thrombosis \& Hemostasis 2010: impact factors and highest-cited articles from 2008 to 2009. Semin Thromb Hemost 2011;37(8):863-868

11 Favaloro EJ. Editorial. Welcome to Seminars in Thrombosis \& Hemostasis 2013. Semin Thromb Hemost 2013;39(1):5-9

12 Avanzini F, Bertele V, Pistotti V, Mannucci PM, Garattini S. Solicited self-referencing undermines the credibility of researchers and journals. J Thromb Haemost 2012;10(3):481-482

13 Favaloro EJ. Editorial. Welcome to Seminars in Thrombosis and Hemostasis- 2008!. Semin Thromb Hemost 2008;34:1-2

14 Schiff D. Eulogy. Eberhard Mammen, M.D. 1930-2008. Semin Thromb Hemost 2008;34:305-306

15 Favaloro EJ. Editorial. Semin Thromb Hemost 2008;34:307-308

16 Favaloro EJ. Editorial: Welcome to a special issue of Seminars in Thrombosis and Hemostasis-the closing issue for 2008. Semin Thromb Hemost 2008;34:693-696

17 Favaloro EJ. A tribute to Eberhard F. Mammen, M.D. (1930-2008). Semin Thromb Hemost 2008;34(8):703-707

18 Rak J. Microparticles in cancer. Semin Thromb Hemost 2010; 36(8):888-906

19 Nagy JA, Chang SH, Shih SC, Dvorak AM, Dvorak HF. Heterogeneity of the tumor vasculature. Semin Thromb Hemost 2010; 36(3):321-331

20 Lippi G, Franchini M, Favaloro EJ, Targher G. Moderate red wine consumption and cardiovascular disease risk: beyond the "French paradox". Semin Thromb Hemost 2010;36(1):59-70

21 Amabile N, Rautou PE, Tedgui A, Boulanger CM. Microparticles: key protagonists in cardiovascular disorders. Semin Thromb Hemost 2010;36(8):907-916

22 Lacroix R, Robert S, Poncelet P, Dignat-George F. Overcoming limitations of microparticle measurement by flow cytometry. Semin Thromb Hemost 2010;36(8):807-818

23 Köse O, Zimmerhackl LB, Jungraithmayr T, Mache C, Nürnberger J. New treatment options for atypical hemolytic uremic syndrome with the complement inhibitor eculizumab. Semin Thromb Hemost 2010;36(6):669-672

24 Fava C, Montagnana M, Favaloro EJ, Guidi GC, Lippi G. Obstructive sleep apnea syndrome and cardiovascular diseases. Semin Thromb Hemost 2011;37(3):280-297

25 Favaloro EJ. Von Willebrand disease: local diagnosis and management of a globally distributed bleeding disorder. Semin Thromb Hemost 2011;37(5):440-455

26 de Moerloose P, Boehlen F, Neerman-Arbez M. Fibrinogen and the risk of thrombosis. Semin Thromb Hemost 2010;36(1):7-17
27 Tse D, Stan RV. Morphological heterogeneity of endothelium. Semin Thromb Hemost 2010;36(3):236-245

28 Volz HC, Kaya Z, Katus HA, Andrassy M. The role of HMGB1/RAGE in inflammatory cardiomyopathy. Semin Thromb Hemost 2010; 36(2):185-194

29 Levi M, Schultz M, van der Poll T. Disseminated intravascular coagulation in infectious disease. Semin Thromb Hemost 2010; 36(4):367-377

30 Zhou Z, Nguyen TC, Guchhait P, Dong JF. Von Willebrand factor, ADAMTS-13, and thrombotic thrombocytopenic purpura. Semin Thromb Hemost 2010;36(1):71-81

31 Wiinberg B, Kristensen AT. Thromboelastography in veterinary medicine. Semin Thromb Hemost 2010;36(7):747-756

32 Tufano A, Coppola A, Cerbone AM, Ruosi C, Franchini M. Preventing postsurgical venous thromboembolism: pharmacological approaches. Semin Thromb Hemost 2011;37(3):252-266

33 Gonzalez E, Pieracci FM, Moore EE, Kashuk JL. Coagulation abnormalities in the trauma patient: the role of point-of-care thromboelastography. Semin Thromb Hemost 2010;36(7):723-737

34 Favaloro EJ. Laboratory testing in disseminated intravascular coagulation. Semin Thromb Hemost 2010;36(4):458-467

35 Key NS, Mackman N. Tissue factor and its measurement in whole blood, plasma, and microparticles. Semin Thromb Hemost 2010; 36(8):865-875

36 Linkins LA, Warkentin TE. Heparin-induced thrombocytopenia: real-world issues. Semin Thromb Hemost 2011;37(6):653-663

37 Lippi G, Franchini M, Favaloro EJ. Thrombotic complications of erythropoiesis-stimulating agents. Semin Thromb Hemost 2010; 36(5):537-549

38 Franchini M, Di Minno MN, Coppola A. Disseminated intravascular coagulation in hematologic malignancies. Semin Thromb Hemost 2010;36(4):388-403

39 Daub K, Seizer P, Stellos K, et al. Oxidized LDL-activated platelets induce vascular inflammation. Semin Thromb Hemost 2010; 36(2):146-156

40 Phang M, Lazarus S, Wood LG, Garg M. Diet and thrombosis risk: nutrients for prevention of thrombotic disease. Semin Thromb Hemost 2011;37(3):199-208

41 Lassila R, Antovic JP, Armstrong E, et al. Practical viewpoints on the diagnosis and management of heparin-induced thrombocytopenia. Semin Thromb Hemost 2011;37(3):328-336

42 Franchini M, Lippi G. Recombinant activated factor VII: mechanisms of action and current indications. Semin Thromb Hemost 2010;36(5):485-492

43 Koenen RR, Weber C. Platelet-derived chemokines in vascular remodeling and atherosclerosis. Semin Thromb Hemost 2010; 36(2):163-169

44 Flaumenhaft R, Mairuhu AT, Italiano JE. Platelet- and megakaryocytederived microparticles. Semin Thromb Hemost 2010;36(8):881-887

45 Karpman D, Sartz L, Johnson S. Pathophysiology of typical hemolytic uremic syndrome. Semin Thromb Hemost 2010;36(6):575-585

46 Targher G, Zoppini G, Moghetti P, Day CP. Disorders of coagulation and hemostasis in abdominal obesity: emerging role of fatty liver. Semin Thromb Hemost 2010;36(1):41-48

47 Ochoa CD, Wu S, Stevens T. New developments in lung endothelial heterogeneity: Von Willebrand factor, P-selectin, and the WeibelPalade body. Semin Thromb Hemost 2010;36(3):301-308

48 Khankin EV, Royle C, Karumanchi SA. Placental vasculature in health and disease. Semin Thromb Hemost 2010;36(3):309-320

49 Orth D, Würzner R. Complement in typical hemolytic uremic syndrome. Semin Thromb Hemost 2010;36(6):620-624

50 Turecek PL, Schrenk G, Rottensteiner H, et al. Structure and function of a recombinant von Willebrand factor drug candidate. Semin Thromb Hemost 2010;36(5):510-521

51 Stellos K, Seizer P, Bigalke B, Daub K, Geisler T, Gawaz M. Platelet aggregates-induced human $\mathrm{CD} 34+$ progenitor cell proliferation and 
differentiation to macrophages and foam cells is mediated by stromal cell derived factor 1 in vitro. Semin Thromb Hemost 2010;36(2): 139-145

52 De Franceschi L, Cappellini MD, Olivieri O. Thrombosis and sickle cell disease. Semin Thromb Hemost 2011;37(3):226-236

53 Allman-Farinelli MA. Obesity and venous thrombosis: a review. Semin Thromb Hemost 2011;37(8):903-907

54 Maas C, Oschatz C, Renné T. The plasma contact system 2.0. Semin Thromb Hemost 2011;37(4):375-381

55 Trigg DE, Wood MG, Kouides PA, Kadir RA. Hormonal influences on hemostasis in women. Semin Thromb Hemost 2011;37(1): 77-86

56 Muszbek L, Bereczky Z, Bagoly Z, Shemirani AH, Katona E. Factor XIII and atherothrombotic diseases. Semin Thromb Hemost 2010; 36(1):18-33

57 Little KM, Smalley DM, Harthun NL, Ley K. The plasma microparticle proteome. Semin Thromb Hemost 2010;36(8):845-856

58 Molema G. Heterogeneity in endothelial responsiveness to cytokines, molecular causes, and pharmacological consequences. Semin Thromb Hemost 2010;36(3):246-264
59 Lisman T, Porte RJ. The role of platelets in liver inflammation and regeneration. Semin Thromb Hemost 2010;36(2):170-174

60 Dragon-Durey MA, Blanc C, Garnier A, Hofer J, Sethi SK, Zimmerhackl LB. Anti-factor $\mathrm{H}$ autoantibody-associated hemolytic uremic syndrome: review of literature of the autoimmune form of HUS. Semin Thromb Hemost 2010;36(6):633-640

61 Coppola A, Tagliaferri A, Franchini M. The management of cardiovascular diseases in patients with hemophilia. Semin Thromb Hemost 2010;36(1):91-102

62 Bigalke B, Krämer BF, Seizer P, Fateh-Moghadam S, Gawaz M, Lindemann S. Diagnostic and therapeutic potentials of platelet glycoprotein VI. Semin Thromb Hemost 2010;36(2):203-211

63 van der Post JA, Lok CA, Boer K, Sturk A, Sargent IL, Nieuwland R. The functions of microparticles in pre-eclampsia. Semin Thromb Hemost 2011;37(2):146-152

64 Key NS, Kwaan HC. Microparticles in thrombosis and hemostasis. Semin Thromb Hemost 2010;36(8):805-806

65 Favaloro EJ, Lippi G, Franchini M. Coagulopathies and thrombosis: usual and unusual causes and associations, part III. Semin Thromb Hemost 2010;36(1):1-5 